Research, part of a Special Feature on Public policies and management of rural forests: lasting alliance or fool's dialogue?

\title{
Resilience of Sweet Chestnut and Truffle Holm-Oak Rural Forests in Languedoc-Roussillon, France: Roles of Social-Ecological Legacies, Domestication, and Innovations
}

\author{
$\underline{\text { Yildiz Aumeeruddy-Thomas }}^{1}{ }^{1}$ Clara Therville $^{2}{ }^{\text {Cedric Lemarchand }}{ }^{3}$, Alban Lauriac $^{4}{ }^{\text {, and Franck Richard }}{ }^{1}$
}

\begin{abstract}
The Cévennes sweet chestnut (Castanea sativa Mill.) forest-orchards and the holm-oak (Quercus ilex L.) black truffle (Tuber melanosporum Vittad.) associations of the garrigue in Languedoc-Roussillon have suffered a century of decline because of great reductions of rural populations and lack of understanding of the ecological and social dimensions of these rural forests by sectorial public agencies. Levels of tree and forest domestication alternated during historical periods in parallel with statuses of disorganization and reorganization of local social groups. Social-ecological legacies intrinsically linked to trees, forests, and landscape domestication, as well as knowledge, social, and technical practices have been mobilized and provided a basis for knowledge innovations, new domestications, uses, and new institutional networks related to changes in social setups. Collective actions emerging from local needs to revive territories in a modern context, cross-scale and reciprocal exchanges of rural and scientific knowledge, as well as institutional changes are interrelated variables that have enabled innovations and have increased resilience of these rural forests. This paper opens new avenues for future research on the interplay between the effects of social-ecological legacies and innovations on the resilience of social-ecological systems.
\end{abstract}

Key Words: Cévennes, chestnut, domestication, garrigue, holm-oak black truffle association, innovations, resilience, rural forests, social-ecological legacies

\section{INTRODUCTION}

Reflections on resilience and adaptability in social-ecological systems (SESs) underline the importance of traditional ethnoecological knowledge and their adaptive nature (Berkes et al. 2003, Folke et al. 2003). Innovations based on crossscale interactions between local and extra-local adaptations and transformations are emerging characteristics of the resilience of SESs (Gunderson and Holling 2002, Walker et al. 2004, Anderies et al. 2006). The case study of Barthel et al. (2010) linking social-ecological memory to the restoration of urban gardening practices raises the question of transgenerational knowledge transmissions and collective memories attached to practices, plants, and ecosystems in the resilience of SESs.

We explore how knowledge and practices of present day local farmers, relying on rural forests that have survived a long period of crisis verging on collapse, have enabled renewal processes. We aim in particular at understanding the interplay between local social-ecological legacies attached to biocultural elements such as domesticated trees, forests, landscapes, and present empirical practices and exchanges with extra-local and scientific knowledge. We compare renewal processes of two rural forests: the sweet chestnut (Castanea sativa Mill.) forest-orchards of the Cévennes and the black truffle (Tuber melanosporum Vittad.) holm-oak (Quercus ilex L.) association of the scrubland open forest (garrigue) in the region of Languedoc-Roussillon (hereafter
LR). We compare ongoing movements to relaunch production of these rural or domestic forests that started in the 1950s in the context of changing economics and policies.

Rural or domestic forests (RFs) are managed by farmers and are an element of agroecosystems, as opposed to forests as defined by conventional forestry. They carry patrimonial values, are embedded in local territories, and have specific socio-political histories (Michon et al. 2007, Genin et al. 2010).

\section{METHODS}

Our research methods mainly draw from ethnoecological and ecological studies conducted between 2007 and the present. We collected data on remnants of past knowledge and practices through conducting a series of open interviews with the oldest inhabitants of these communities ( 70 to 80 years old; hereafter elders). Their knowledge refers to their individual practices and transmissions of the value of these RFs by their parents and grandparents, born in the 1870 to 1880 s. The latter had witnessed the virtual collapse of these RFs. The vision and knowledge of these inhabitants have been shaped not only by their individual practices, but also by collective memories and practices linked to shared and transmitted learning processes attached to trees, forests, and landscapes, a process termed as social-ecological memories by Barthel et al. (2010). Because they lived in a period of crisis, their understanding forms the basis upon which the region's current inhabitants, i.e., their

${ }^{1} \mathrm{CNRS}$, Centre d'Ecologie Fonctionnelle et Evolutive, UMR 5175, ${ }^{2}$ University of Montpellier II, ${ }^{3}$ University Montpellier II, ${ }^{4}$ Centre Régional de la Propriété Forestière (CRPF) 
children but also newcomers, agricultural extension agents, etc., have relied. We cross-checked findings by screening literature on the history of chestnut in Europe and the Cévennes (Bruneton-Governatori 1984, Pitte 1986) and of truffle production in France, the latter mostly compiled in old documents (de Bosredon 1887, Chatin 1892). We also analyzed changes in knowledge, practices, and socio-cultural networks in the principal local professional journals such as La Montagne qui Bouge and Le Trufficulteur Français. Practices of the children and grandchildren of these oldest inhabitants, and of newcomers to the region, were described during numerous field visits. Newcomers in Cévennes, known as neo-rurals, represent protesters from the 1968 revolts in France who left urban areas as a sign of protest against dominant social and political values. Interviews were conducted with key people involved in the revival process including technicians of socio-professional organizations such as the Chamber of Agriculture ("Chambre d'Agriculture") and the Centre Régional de la Propriété Forestière (hereafter CRPF), as well as with entrepreneurs involved in the networks that commercialize products of rural forests. Data were also collected by direct observations of practices and through multiple open discussions during fairs and meetings. These various sets of data enabled us to reconstruct the history of collective actions and institutional changes. Chestnut or holmoak management areas were characterized and mapped to evaluate trends in landscape transformations. Detailed landscape ecological studies aiming at identifying effects of new practices and uses on tree populations, and definition of new land use units were conducted by Lemarchand (2009) and Therville (2009).

Data collected were used to analyze the historical context of the collapse and the processes of transmissions and innovations for both RFs. We focused on domestication processes, cross-scale exchanges of knowledge, and institutional changes.

Work on the chestnut RF was conducted in the French Département (county) of Lozère, mainly in the French Commune (rural district) of Saint Martin de Lansuscle located in the southern valleys of the Cévennes. Soils are on schistdominated substrates, and are acidic and considered to be of low fertility. The truffle holm-oak forests form patches scattered in the vast garrigue vegetation of LR located on calcareous bedrock (Fig 1). We worked in the Uzès Rural district, known as the truffle capital of LR and a central place for black truffle production and trade in the region.

\section{HISTORICAL CHANGES IN THE TWO RURAL FORESTS AND THEIR DECLINE}

These two RFs progressively declined from the end of the 19th century through the first half of the 20th century because of agricultural intensification in the arable plains (Grove and Rackham 2001, Sutherland 2002, Hall et al. 2003), great population losses during two world wars, and the exodus of rural populations to urban centers. Negative perceptions of farmers' knowledge and practices were associated with chestnut production until the 1980s (Dupré 2002). Indeed agronomists and foresters have long accorded insufficient attention to the management of garrigue by rural populations. For instance, foresters discovered incidentally in the $1890 \mathrm{~s}$ that forest plantation could yield truffles but it was only in the 1990s that the forestry sector developed systematic programs for truffle silviculture (Diette and Lauriac 2004) despite the fact that farmers conducted many trials for cultivating oak through planting acorns, which had positive results. Farmers produced locally inoculated seedlings and developed large plantations that have been acknowledged to be productive (Chatin 1892).

Fig. 1. Map of Languedoc-Roussillon and location of the the study sites.

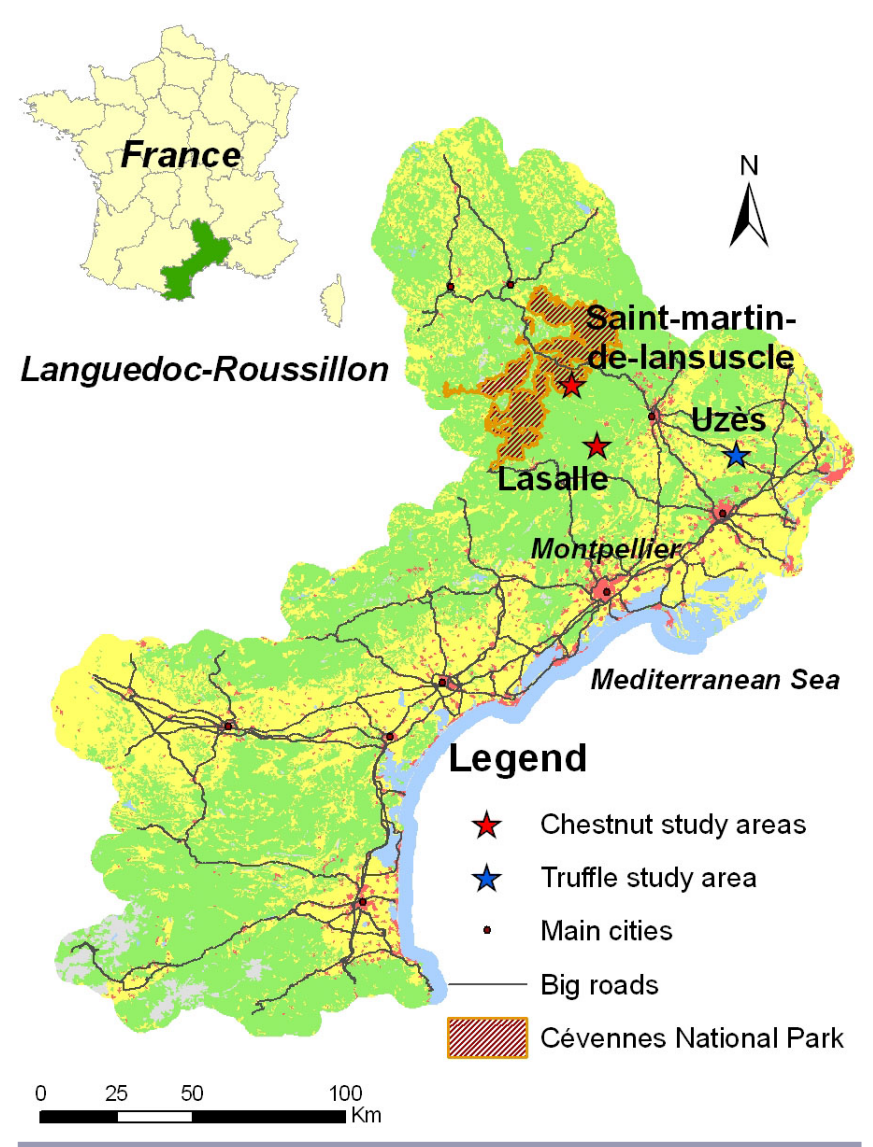

Chestnut RF in the Cévennes comprises large continuous stands dominated by one species, Castanea sativa Mill. This tree was likely transported from Eastern Europe during the period of the Roman Empire along with techniques of grafting of selected varieties onto trees issued from self-sown seeds (Pitte 1986). Grafted chestnut forests therefore reflect an 
apparently natural distribution although it is very likely that chestnuts were first planted by seeds because of an absence of extensive chestnut forests before the Roman period. Chestnut cultivation expanded considerably beginning in the Middle Ages in Cévennes (Travier 2006). At present in Gard, Lozère, and Ardèche counties, about a 100 locally selected varieties of different origins are known and have been utilized as far back as elders can recall (Verdier 2006). This expansion slowly converted natural oak forests into a domesticated forested landscape. The latter reverted at various historical periods of crisis, e.g., pest epidemics, to a natural "bosc" (forest) dominated by spontaneously growing chestnuts, demonstrated by analysis of a long series of land registers (Galzin and Dejean 1986). Favorable periods represented intensive treatment including grafting, pruning, and shaping of individual trees. Mixed in with grafted trees were trees originating from self-sown seeds. These trees, known locally as "bouscasses," were probably few in number relative to grafted trees during these favorable periods. The decline of the chestnut RFs from the end of the 19th century up to the 1970s led to rapid colonization by pines and by Mediterranean shrubs (Fabaceae, Ericaceae), incidentally increasing fire outbreaks (Gondard et al. 2001). Chestnut trees are attacked by a fungus [Cryphonectria parasitica (Murrill) M.E. Barr] producing a canker disease that causes severe damage that often kills the infected tree. By extension, farmers felt that this disease was an attack upon themselves, their territory, and their identity (Pelen 1987). Loss of grafted chestnuts and the absence of supportive agricultural policies led people to sell large tracts of orchards to an important tannin industry that was established in the Cévennes (1860 -1960). Properties were sold and those that remained, under joint possession regimes, could not be sold or managed easily by a third party. Thus, both the social and the ecological components of the overall system were disrupted.

The ecology of the holm-oak truffle association is linked to a centuries-long history of coupled social-ecological processes that converted Mediterranean forests into open savanna-like tree formations (Grove and Rackham 2001, Quézel and Médail 2003). Such transformed habitats created optimal conditions for abundant fruit-body production by the emblematic black truffle (Hall et al. 2003). Gathering truffles has been a productive activity since the Middle Ages in France (Chatin 1892). Tuber melanosporum, the black truffle, is an ascomycete fungus that forms ectomycorrhizae with Quercus ilex, Q. coccifera, and Q. pubescens in Mediterranean garrigue formations. Fruit production is greatest in ecotones between grasslands and holm-oak canopies; pastoral activities create large areas of such ecotones (Callot 1999). The zone around a truffle-infected host tree is profoundly transformed; volatile compounds produced by the mycelium inhibit growth of herbaceous plants, forming so-called "brûlé" or burnt areas (Fig. 2). Since the end of the 19th century, most farmers engaged in modern agriculture, especially viticulture in arable lands. In areas unsuitable for mechanized agriculture, including the open habitats where truffles thrive, vegetational changes caused by shifts in agricultural and animal husbandry practices led to closed-canopy systems (Scarascia-Mugnozza et al. 2000). Despite the fall of the agro-silvo-pastoral system, truffle production peaked at the beginning of the 20th century because vine fields abandoned after the Phyloxera crisis (1860s) were colonized by holm-oak and were also actively planted with holm-oak by farmers. They inoculated seedlings by adding mycelium and small pieces of truffle to produce what was known as "plants planteurs" (Chatin 1892). However, truffle production inexorably decreased in the large tracts of abandoned garrigue.

Fig. 2. The holm-oak (Quercus ilex L.) and black truffle (Tuber melanosporum Vittad.) rural forest; development of burnt and successional stages after plantation. (a) Burnt areas surrounding new inoculated holm-oak plantations in abandoned vineyards; (b) A burnt area at the foot of a 30year-old holm-oak with traces of branches lopping in the lower part of the trunk; (c) Old inoculated holm-oak plantation in Uzès managed as woods.

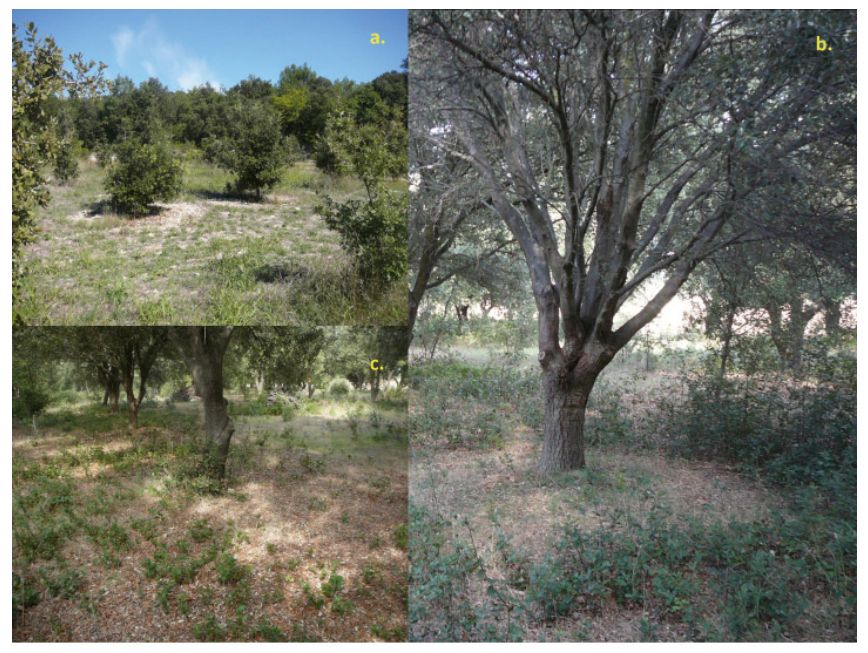

Roles of these RFs in the rural economy follow parallel but not completely congruent histories, as shown in Table 1 . The decline of activities beginning in the mid-19th century, as discussed by the region's oldest inhabitants and by agricultural agents who arrived in the 1980s, led to the disruption of commercial circuits (Table 2). Today, the principal market for chestnuts is for consumption by city dwellers as delicacies in festive dishes (chestnuts sell at 1 euro per kilo locally and are bought at 3 to 5 euro $/ \mathrm{kg}$ in towns). These uses favor varieties that produce large nuts, varieties often considered less tasty than those still preferred today by young Cévenols and neorural producers. 
Table 1. Past and present chestnut (Castanea sativa Mill.) and holm-oak (Quercus ilex L.) rural forests (RFs) use. (Sources: primary data and bibliographic sources Chatin 1892, Pelen 1987, Dalonis 1996, and Travier 2006).

\begin{tabular}{|c|c|c|c|c|c|c|}
\hline $\begin{array}{l}\text { Past uses of chestnut } \\
\text { RF }\end{array}$ & $\begin{array}{l}\text { Past uses of holm- } \\
\text { oak and truffle RF }\end{array}$ & $\begin{array}{l}\text { Parallel past } \\
\text { economic activities } \\
\text { in chestnut RF }\end{array}$ & $\begin{array}{l}\text { Parallel past } \\
\text { economic activities, } \\
\text { holm-oak and } \\
\text { truffle RF }\end{array}$ & $\begin{array}{l}\text { Present day uses } \\
\text { chestnut RF }\end{array}$ & $\begin{array}{l}\text { Present day uses } \\
\text { holm-oak and } \\
\text { truffle RF }\end{array}$ & $\begin{array}{l}\text { Present day parallel } \\
\text { economic activities } \\
\text { of both RFs }\end{array}$ \\
\hline $\begin{array}{l}\text { Main staple food for } \\
\text { humans; dried } \\
\text { chestnuts eaten in } \\
\text { soups off season. } \\
\text { Fresh chestnuts sold } \\
\text { on local markets }\end{array}$ & $\begin{array}{l}\text { Truffles for local } \\
\text { consumption and } \\
\text { local markets. Sold to } \\
\text { brokers collecting } \\
\text { truffles for } \\
\text { transformers living in } \\
\text { urban areas }\end{array}$ & $\begin{array}{l}\text { Silk industries } \\
\text { (17th - 19th } \\
\text { century) }\end{array}$ & $\begin{array}{l}\text { Viticulture and } \\
\text { wine industry }\end{array}$ & $\begin{array}{l}\text { Used only in } \\
\text { specific dishes } \\
\text { locally and in urban } \\
\text { areas and mainly in } \\
\text { fresh form or } \\
\text { transformed: e.g., } \\
\text { "crème de } \\
\text { marron" }\end{array}$ & $\begin{array}{l}\text { Consumed locally } \\
\text { at family level but } \\
\text { mainly sold directly } \\
\text { during fairs and on } \\
\text { local markets }\end{array}$ & Agro-tourism \\
\hline $\begin{array}{l}\text { Wood used for fuel } \\
\text { and construction }\end{array}$ & $\begin{array}{l}\text { Wood used for fuel } \\
\text { and construction }\end{array}$ & $\begin{array}{l}\text { Wood used in } \\
\text { mines and for wood } \\
\text { charcoal industries }\end{array}$ & $\begin{array}{l}\text { Fuel wood and } \\
\text { charcoal industry } \\
\text { during the 19th } \\
\text { century }\end{array}$ & Timber production & & Secondary dwellers \\
\hline $\begin{array}{l}\text { Payment of taxes } \\
\text { (Middle Ages) }\end{array}$ & & $\begin{array}{l}\text { Secondary } \\
\text { products: } \\
\text { mushroom (e.g., } \\
\text { Boletus) and game }\end{array}$ & $\begin{array}{l}\text { Secondary } \\
\text { products: aromatic } \\
\text { plants (thyme), } \\
\text { game }\end{array}$ & $\begin{array}{l}\text { Secondary } \\
\text { products: Boletus } \\
\text { and game used } \\
\text { locally and sold in } \\
\text { informal market } \\
\text { circuits }\end{array}$ & $\begin{array}{l}\text { Secondary product: } \\
\text { game, aromatic } \\
\text { plants (e.g., thyme) }\end{array}$ & \\
\hline $\begin{array}{l}\text { Chestnuts and leaves: } \\
\text { fodder for feeding } \\
\text { animals and forest } \\
\text { used as grazing } \\
\text { grounds for sheep } \\
\text { flocks } \\
\text { A political refuge } \\
\text { area during the } \\
\text { Catholic-Protestant } \\
\text { religious wars in } \\
\text { Cévennes in the } 17 \text { th } \\
\text { century }\end{array}$ & $\begin{array}{l}\text { Acorns of holm-oak } \\
\text { and tree leaves: } \\
\text { fodder for animals } \\
\text { and forest used as } \\
\text { grazing grounds for } \\
\text { large flocks of sheep }\end{array}$ & $\begin{array}{l}\text { Pigs fed with } \\
\text { chestnuts sold once } \\
\text { a year. Goat milk } \\
\text { and sheep meat sold } \\
\text { and used locally }\end{array}$ & $\begin{array}{l}\text { Sheep and goat } \\
\text { products used } \\
\text { locally and sold }\end{array}$ & $\begin{array}{l}\text { Goat cheese } \\
\text { ("pélardon" with } \\
\text { Protected } \\
\text { Designation of } \\
\text { Origin). Sheep meat } \\
\text { sold } \\
\text { Area of refuge for } \\
\text { young unemployed } \\
\text { urban dwellers }\end{array}$ & & $\begin{array}{l}\text { Environmental } \\
\text { projects }\end{array}$ \\
\hline
\end{tabular}

Truffles represented a highly appreciated product of the holmoak RF primarily managed as grazing grounds for large flocks of sheep (Table 1). Although the secrecy surrounding truffle production makes it difficult to evaluate production, Chatin (1892) amassed extensive data, assessing amounts collected in 54 counties. He estimated that some 2000 tons were collected annually for national markets and for export. The production was at its peak at the end of the 19th century but declined slowly thereafter, reaching an average amount of 20 tons in 1996 (Dalonis 1996). Despite recent technical innovations, i.e., techniques of inoculation of the host tree developed by the National Institute for Agronomic Research (INRA), production in 2005 was only 40 tons (FFT 2005). The traditional truffle economy collapsed and the rarity of the product is among the reasons why truffle has become very expensive in France (up to 300 euros or more per $\mathrm{kg}$ in the 1970s and more than 800 euros/kg in 2012). In 1868, a kilo of truffles was worth 36 euros and the export price was equivalent to about 36 to 210 euros ( 1 franc in $1900^{[1]}$ equivalent to 3.6 euros; INSEE 2011, www.insee.fr/fr/indicateurs/indic cons/g uide_lecture tableaux_telechargeables.pdf). Commercial brokers in Uzès and other truffle production areas in France controlled benefits with secretive approaches on amounts and prices, nurturing mistrust between growers. In the Uzès area, people turned again to truffles in the 1960s because of their high price, attachment to their territory, and disillusionment with modern agriculture (Table 2).

Chestnut and truffle economies are in many respects very different; the products did not serve the same purposes locally and their production did not require the same types of labor forces. However, both economies were inscribed in the context of the transformation of a whole agroecosystem with common traits, i.e., the reliance upon forest dynamics and similar products, e.g., dry fruits (chestnuts vs. acorns), mushrooms (boletes vs. truffles), wood, charcoal, and timber, livestock products (pigs, goats, and sheep), secondary products such as medicinal and aromatic plants (e.g., thyme), and game products (Table 1). The major differences between the two systems lie in the fact that farmers were unable to predict truffle production whereas chestnuts resulted from precise techniques 
Table 2. Elements of discourse illustrating different actors' perceptions about the decline and renewal of chestnut (Castanea sativa Mill.) and holm-oak (Quercus ilex L.) rural forests (RFs).

\begin{tabular}{|c|c|c|}
\hline Actors & Theme & Elements of discourse \\
\hline \multicolumn{3}{|l|}{ Chestnut RF } \\
\hline old inhabitant & trade & $\begin{array}{l}\text { "Commercial outlets became very poor. Bags of chestnuts, with a mixture of different } \\
\text { varieties, more or less well-preserved, were sold to the few brokers left, and many rotted by } \\
\text { the road sides, a disaster." }\end{array}$ \\
\hline old inhabitant & reversion to wild status & $\begin{array}{l}\text { "There were no people to accompany the flocks of sheep and the "bouscasses' were growing } \\
\text { everywhere. We had difficulties collecting chestnuts." }\end{array}$ \\
\hline old inhabitant & shaping landscape & $\begin{array}{l}\text { "It is soil depth which counts for chestnut trees that's why we make terraces... without the } \\
\text { 'tancats'(constructions to divert water), terraces would just be destroyed by heavy } \\
\text { rainfall." }\end{array}$ \\
\hline neo-rural & shaping landscape & $\begin{array}{l}\text { "We maintain the walls and terraces but we are unable to reconstruct new ones. Some } \\
\text { people in other valleys have engaged in an association of constructers of terraces. It is } \\
\text { interesting but we do not have time." }\end{array}$ \\
\hline old inhabitant & old and new uses & $\begin{array}{l}\text { "In town, chestnuts are now used like potatoes in sauces but these people do not know the } \\
\text { real taste of chestnuts. We eat the chestnuts simply boiled or roasted so we can really } \\
\text { appreciate their taste. These big and pretty varieties have no taste." }\end{array}$ \\
\hline neo rural & new uses & $\begin{array}{l}\text { "We produce fresh peeled chestnuts which are sold to people in town. Only big and non- } \\
\text { partitioned varieties such as the marron Dauphine are accepted. We sell mixed varieties to } \\
\text { produce the famous "crème de marron.", }\end{array}$ \\
\hline
\end{tabular}

\section{Holm-oak truffle RF}

old inhabitant

old inhabitant social-ecological legacies

old inhabitant

young producer

territory and trade

\begin{abstract}
"The country was dying out... the garrigue was slowly being invaded and not producing anything. There were many risks of fire outbreaks. In addition, the young people were facing major difficulties. For instance, my son lost the whole of his harvest of asparagus because of this disease called fusariose. I myself lost a whole lorry of potatoes which rotted by the road. My wife sold a large basket of truffles for the price of this whole lorry!"

"Our grandparents not only led the flocks of sheep, but also pruned the trees and collected firewood. When looking at the brûlé you need to see whether the soil conditions are favorable to truffle, including humidity and temperature in relation to wind systems as well as light. Our grandparents knew truffle 'places' they could detect from experience and with the help of trained truffle dogs Languedoc."

"Our parents believed that sheep flocks dispersed the truffle spores and mycelium through trampling of truffles, or that rabbits or field mice consume the truffles and dispersed the spores."

"In old plantations passed on by our father we favor seedlings and eliminate old trees. Slowly these plantations look very much like a truffle wood."

"Besides we still keep truffle woods close to our plantations because we believe that this will favor truffle production even within the cultivated plots. We however have to irrigate because of dry summers."
\end{abstract}

for increasing production. Owing to the rarity and high value of the product, truffle production is shrouded in secrecy, whereas knowledge about chestnuts, including production techniques, and the chestnut varieties are widely shared.

\section{TRANSMISSIONS AND INNOVATIONS}

\section{Domestication of landscapes and species in process}

Both RFs are based on practices acting at the landscape and individual tree levels. For centuries, the Cévenols shaped the slopes by building terraces and taming the water system, thus changing soil conditions to coincide with ecological requirements of chestnut trees, which thrive in deep soil (Table 2 ). Only a few elders and senior farmers are involved in rebuilding or maintaining terraces. Neo-rurals perpetuate some of the common local values, sometimes with even more interest than young Cévenols, as a way of belonging to the place (Table 2). These different categories of farmers rely on transmitted elements of this domesticated landscape and forest, such as old terraces, grafted varieties nurtured by generations of Cévenols, named and associated with specific uses, and distributed in a nonhaphazard way in patches linked to past transmissions. Century-old chestnut trees are revived with a recently introduced drastic pruning technique, to which the old trees react positively (Fig. 3). By manipulating these legacies, as well as new techniques, they produce innovations, including new products mainly destined for urban consumers (Table 1). Current producers are engaged in grafting chestnut trees, an activity they learned from the experience of elders and during collective training sessions by agricultural 
extension agents. Whereas older Cévenols consider chestnuts from "bouscasses" (trees originating from self-sown seedlings, not from grafted trees) to be unfit for consumption except in times of famine, newcomers do not share this absolute rejection; some of them keep and extensively use the nuts from nongrafted trees, selecting the best trees that they may graft on a trial basis. They have thus taken the first steps toward new varietal creations. Chestnuts originating from bouscasses are usually considered to have an astringent taste. However, owing to the continuous gene flow between selected varieties and trees from self-sown seeds, some of the latter do produce good sweet chestnuts.

Fig. 3. Grafting and renovation processes of chestnut (Castanea sativa Mill.) rural forest: a transgenerational construction of tree architecture. (a) The ring graft, the oldest grafting system in Cévennes; (b) Diversity of grafting techniques (Source: Travier and Pelen 1973); (c) Old grafted tree; (d) Severe pruning to restore production of old grafted trees; (e) Coppices used as rootstock for new grafts.

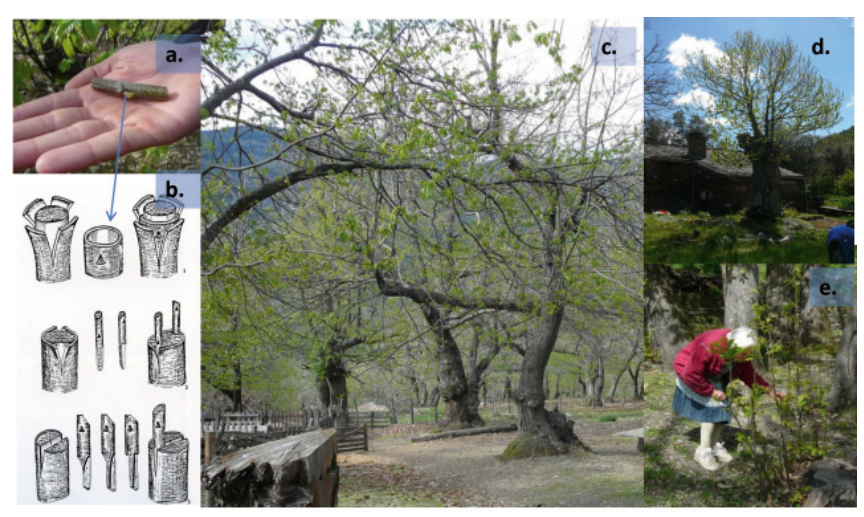

New land management systems and new uses of the products create selection pressures and an ongoing domestication that builds on past techniques, the accumulated stock of varieties, and recombinant plants from self-sown seeds. Some farmers have developed new practices such as chestnut timber production in closed canopy forests, with advice and support from the CRPF. Others, supported by the European Common Agricultural Programme schemes for livestock breeding, use large tracts of chestnut forests exclusively for grazing flocks of sheep in their understory; they pay little attention to the diversity of varieties. Some other farmers have restored up to 5 ha of coppicing chestnut trees, resulting from orchards cut for the tannin industry in the 1950s, through grafting onto them only one or two traditional varieties that have high commercial value. Their activities are supported by regional and national schemes for chestnut orchard restoration under the direction of the Syndicat Interrégional-Montagne Elevage (SIME). These different approaches have led to specialized spaces with specialized productions: fruit, wood, and animal husbandry.
These production areas support different tending and animal husbandry practices. However, other areas remain totally abandoned. Thus, in Saint Martin de Lansuscle, seven types of chestnut orchards were identified and form a new landscape mosaic (Fig. 4, 5).

Fig. 4. Diversity of spaces and habitats in chestnut (Castanea sativa Mill.) rural forest in relation to types of practices. (a) Old abandoned chestnut rural forest; (b) Managed chestnut forests for timber production; (c) Terraced fruit orchards; (d) Tended fruit orchards used by sheep as grazing land.

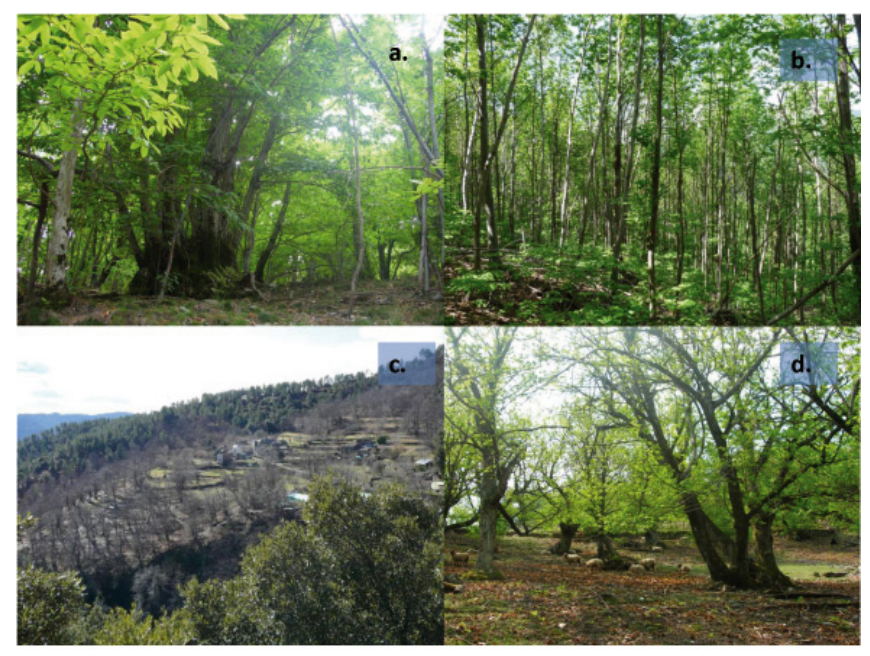

Old truffle gatherers, known as "caveurs" in Uzès, explain that during the times of their grandfathers the whole garrigue was maintained as open vegetation by their flocks and contained many good places for truffle production. Many beliefs about truffle ecology still exist today (Table 2). Young producers constantly experiment with techniques sometimes inspired by ancient practices. Their fathers planted acorns to produce new holm-oak plantations and managed truffle woods (Table 2). Some 30- to 50-year-old plantations have evolved into woodlands as a result of natural dynamics that farmers have consciously favored (Table 2, Fig. 2). Farmers create diversity at the landscape level by diverse degrees of tending and by allowing variable levels of understory vegetation. This creates a mosaic of habitats and favors biodiversity (Therville 2009). The heterogeneity in new landscape mosaics resulting from the renewal movements is shown in Fig. 6.

Changing landscapes based on new mosaics of "wild" and cultivated areas of different ages cohabit with new inoculated holm-oak plantations that have swamped the market since the 1970s. The intermingling of past legacies and new practices resulting from ongoing experimentations, forms a new domesticated "truffle-landscape." It differs from the ancient garrigue, and the innovative practices on individual trees and 
the "brûlé" (burnt areas) around them, such as eliminating specific species within the burnt area and favoring others, watering at specific seasons, tilling, pruning, etc., show domesticating approaches in progress.

Fig. 5. Distribution of different types of chestnut (Castanea sativa Mill.) rural forests at the landscape level in the rural District of Saint Martin de Lansuscle, LanguedocRoussillon.

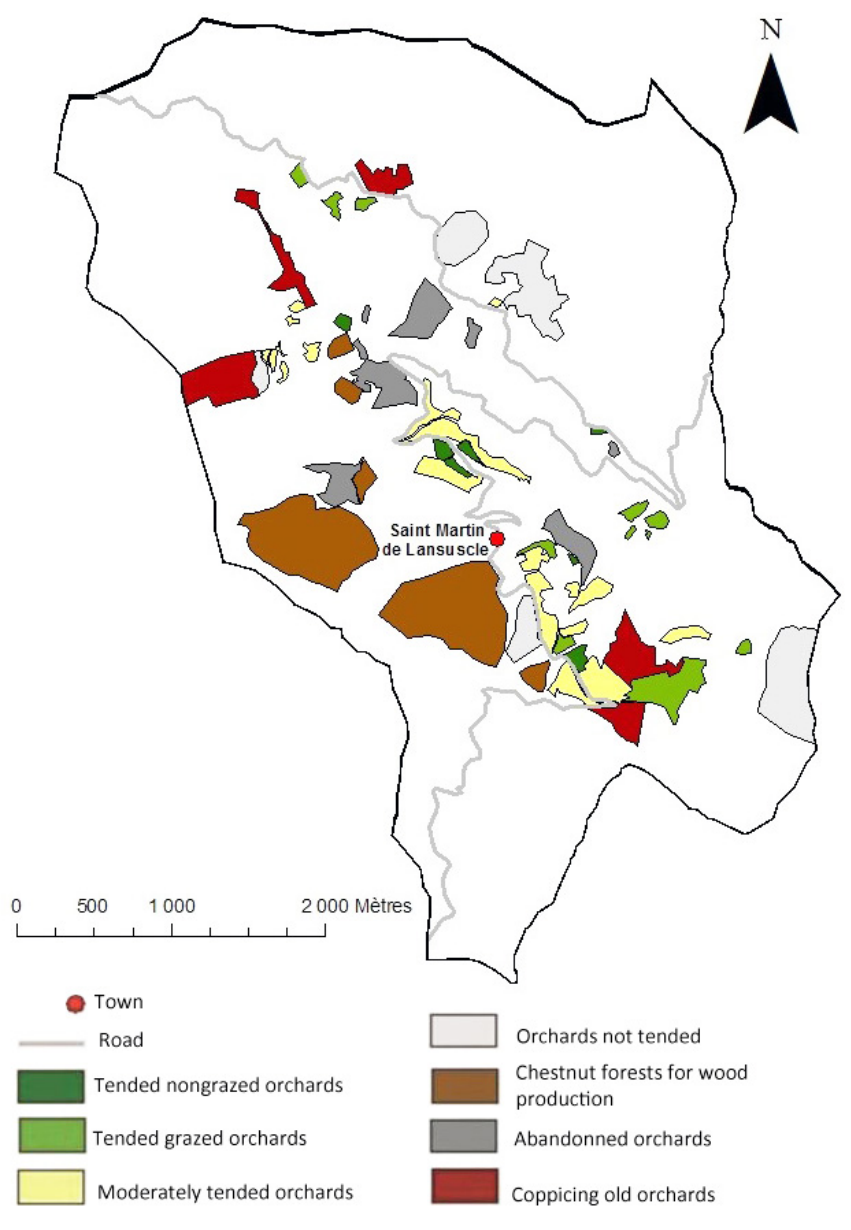

However, the domestication of truffle appears to be far more complex than that of chestnut because it involves manipulating a strict mutualism between the tree and the fungus, linked to engineering by humans of a whole ecosystem. Both the ecosystem management and factors affecting the mutualism are still far from being understood by agricultural and forestry sectors or even by scientists (Hall et al. 2007). This is illustrated by the fact that the simple inoculation of the trees proposed by INRA did not give the expected result of a major increase in production (FFT 2005).
Fig. 6. Distribution of holm-oak (Quercus ilex L.) and black truffle (Tuber melanosporum Vittad.) rural forest in cultivation and renovated guarrigue (scrubland-open forest) areas for production of truffle at the landscape level in Uzès, Languedoc-Roussillon.

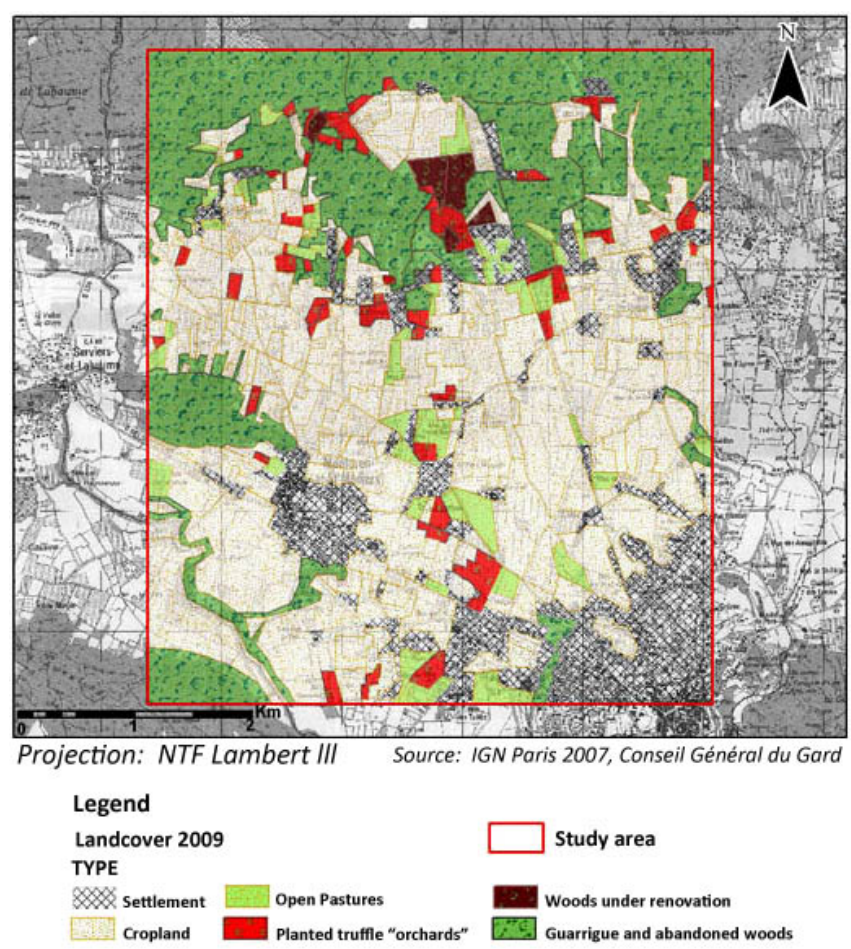

Collective actions and institutional innovations

Innovative institutional approaches were set up for the renewal of both RFs. In the Cévennes, it was in the bleak situation of the 1950s that the first sign of revival appeared through the initiative of a few charismatic Cévenols leaders who had left the region and had created political and economic connections at the national level. These leaders, with the help of chestnut producers and leaders from different chestnut-producing regions, set up a national interprofessional organization, the Comité National Interprofessionnel de la Châtaigne et du Marron(CNICM). This institution requested technical support and funding at the national level. Actions to reconstruct the Cévennes chestnut RFs were driven by the members' understanding of the growing urban demand for chestnuts, especially for large-seeded varieties. The success of relaunching activities in Cévennes started with a collective action, the Lasalle cooperative in 1956. Its aim was to modernize the commercial circuit through investing in 
machines that would sort out different sizes and by organizing collectively the sale of products. Thus was initiated this renewal movement based on a transformation from a household to a collective level of postproduction and selling. Through the creation of the Syndicat Interrégional-Montagne Elevage, mountain agriculture in LR received direct funding from the state through specific programs. The SIME agents recognize that they learned from the elders because they knew little about this form of agriculture before their arrival. These agents played a major role in developing and following up the process of restoring chestnut RFs with a thorough program of on farm experiments with the regional union of chestnut producers (ULRAC) on the basis of contracts with the farmers.

In Uzès, the creation of the Syndicat des trufficulteurs du Gard, established in 1971 by notable truffle gatherers (caveurs) and growers, supported younger farmers especially through their informal networks. The Syndicat was linked to the national level Fédération Française des Trufficulteurs, which established similar groups in other truffle-producing areas in France in an ultimate effort to face the collapse in truffle production (FFT 2005). These organizations were able to influence the development of projects supported by the state, such as the Fond National d'Aménagement et de Développement du Territoire (FORMA). The growing membership of the truffle-growers' association in Uzès increased the power of their representatives in influencing decisions made by the Chambre d'Agriculture, a powerful professional association of farmers that decides courses of action in different agricultural sectors. This mounting influence led to new institutional rearrangements, such as obtaining a specific agent dedicated to truffle development, and facilitated funding requests at both the county and regional levels.

Both in Cévennes and in the garrigue, major institutional changes were implemented through collective action leading to political visibility, increased funding, and ultimately actions that initiated the revival movements, seen in both cases as a means of reviving the territory. The leaders of these movements acted at multiple levels, including mayors, leaders in the Syndicat, truffle growers, and members of the Chambre d'Agriculture. Some individuals acted at several of these levels simultaneously.

\section{Cross-scale exchanges of knowledge and multisectorial inputs from environment, forestry, and agriculture}

In both areas, the new socio-professional organizations facilitated exchange of knowledge between regions and beyond. Chestnut growers visited Portugal and learned the technique of tree restoration through severe pruning, which proved efficient in restoring production. Environmentally oriented agricultural programs in the 1980s supported restoration of chestnut orchards. The CRPF also launched operations to develop silviculture of abandoned chestnut orchards for wood production. Animal husbandry was supported by the European Common Agricultural Program schemes, as well as the development in Cévennes of the geographical indication on goat cheese (DPO Pélardon des Cévennes) supported at the regional level.

Truffle growers also organized visits to different regions. People were "giving access for the first time to their plantations" to groups of truffle growers from other regions to discuss their respective techniques, an approach termed by agricultural agents as "learning by experience" (B. Assenat, personal communication 2010). In the 1970s, environment became an argument that justified the restoration of truffle woods, especially to contain fire outbreaks. Through collective action and political lobbying, the Syndicat obtained funding from the Départment of Gard and later from the region (LR). Another movement took place in the forestry sector, especially in the nearby Department of Lozère, with the help of the CRPF. This semigovernmental institution, whose members are the forest owners, forms a mixed system that favored the emergence of new interest in the forestry sector to find silvicultural solutions for recreating ecotone vegetation in natural garrigue areas (Diette and Lauriac 2004). This tendency rallied truffle growers to reflect on the optimal conditions required by truffle in its "natural" ecosystem. Overall, truffle growers see garrigue restoration practices as too demanding of time and labor and prefer to replant in open areas where they can more easily control natural regrowth.

Collective action in both cases helped develop exchanges with scientific institutions, especially INRA. The latter created new high-yielding hybrid varieties between Castanea sativa and the Japanese chestnut Castanea crenata that offered varying degrees of resistance to chestnut canker. Hypovirulent strains of Cryphonectria parasitica, the causative agent of chestnut canker, were also developed by INRA and distributed at very low cost. They were meant to protect the tree from the virulent disease. These advances marked an important shift in both areas. Some Cévenol farmers who had traditionally grafted their own selection of chestnut varieties onto trees from selfsown seeds from then on obtained grafted chestnuts with a specific choice of traditional varieties selected from agricultural services as well as other high-yielding hybrid varieties developed by INRA.

In the 1970s INRA developed a process to inoculate $T$. melanosporum on tree roots under controlled conditions (Hall et al. 2003). The patented plants were distributed to farmers who benefited from much support from different programs at the local, regional, and national levels. In the garrigue, the situation shifted from self-produced inoculated "plant planteurs," to inoculated plants certified by an external agency (INRA). This favored a shift to planting in arable lands instead of less arable garrigue lands. The plantation of inoculated holm-oak, out of its original ecosystem in the fields, did not give the expected results as said before. This is one of the 
explanations for the stagnation of truffle production in France despite the constant increase since the 1970s in total area planted. For example, 3460 ha of new plantations were established with the help of the state-funded FORMA project in France between 1970 and 1986 (FFT 2005). High plantation densities and irrigation approaches were proposed as part of funding packages that offered free inoculated plants to farmers. Farmers ultimately readjusted the techniques proposed by the project on the basis of their collective knowledge. In both areas, however, these advances boosted renewal activities because they were linked to funding schemes and enhanced experiential learning processes bringing together people from different horizons and knowledge bases, leading to knowledge innovations as well as differentiation of spaces and techniques applied.

\section{DISCUSSION}

In this paper, we show that interactions between socialecological legacies and innovations have been instrumental in the renewal of the chestnut and holm-oak rural forests in LR, despite the context of social-ecological disruption that prevailed. For both RFs examined, people changed the practices exerted upon their RFs and the landscape. Such dynamic changes have been discussed in literature showing the capacity of farmer societies across the world in setting aside old practices to revamp their agroecosystems and economies, while maintaining "the presence of the past in the present," which is one facet of resilience (Dove 1999:61). Although linkages to social-ecological legacies form local identity, the sense of belonging to a place (Dove 2002), innovations and integration of new values, as well as new knowledge and institutions lead to social adaptation and resilience in contexts of changes. Innovations within chestnut and holm-oak RFs follow a long period of crisis during which the society changed, e.g., values attributed to food products, market circuits, knowledge transmission, etc. For example truffle management, which was a highly secretive activity, has become a practice with a higher level of shared knowledge within constituted groups and local institutions.

Social-ecological legacies that evolved with the domestication of trees, forests, and landscapes, have been mobilized and provided a basis for knowledge innovations, new domestications, uses, and institutions. These complex interactions between past and present are very close to the patrimonial construction of RFs discussed by Auclair et al. (2011). They consider managed forest resources in the Moroccan Atlas as elements of patrimony following Ollagnon's (2000) definition of patrimonial management as an adaptive process in time and space of material and immaterial elements by human communities to develop their identity and autonomy. We use the expression of socialecological legacies instead of patrimony to emphasize the evolution of SESs under domestication processes, a subject little discussed by Ollagnon (2000). Domestication is a very helpful concept to understand the evolving nature of tree populations, forests, and landscapes as well as parallel changes in societies, as a result of cumulative efforts linking human practices to natural and ecological dynamics (Gepts et al. 2012). Social-ecological legacies also rely upon cultural memory of shared cognitive and material resources of a given society and the way it acts on natural environments (Nazarea 1998, Barthel et al. 2010).

Social-ecological legacies are linked to cumulated human impacts at different integrated scales from landscape to forest and to tree populations. Landscapes have been shaped and transformed and have in turn produced new habitats that may host species level domestications such as chestnut varieties that are highly adapted to human uses. Truffle production requires subtle microhabitat approaches linked to larger forest level management that has been lost because of the highly secretive approach of truffle production. This generated belief rather than knowledge (Chazoule 2004) and in that respect does not represent a sufficiently shared knowledge system to be able to generate an effective domestication of truffle. The complex interactions between the holm-oak and its mutualist fungus, the black truffle, as well as the management of the "brûlé" remain an unpredictable system that is therefore more vulnerable to major changes. This is shown by the fact that although plantation areas have increased, overall production in France remains very low. Although truffle producers' knowledge has opened up in the context of collective actions, they are now influenced by the modernist agricultural approaches of the 1970s favoring plantations in conventional agricultural plots, which may not be adapted to truffle ecology, a situation of over-domestication denying ecological dynamics and that may affect collective actions for renewal.

Both situations examined call for further reflections on integrated scales of domestication processes as well as its spatio-temporal expression. The situation of chestnut is particularly revealing because it shows shifts over historical periods between more natural forms and highly domesticated states underlining the absence of a stark divide between wild and domesticated forms (Aumeeruddy-Thomas 2010). The new mosaics created at the landscape level in both cases creates flexibility and reversibility and increases resilience through favoring exchanges between wild and highly domesticated compartments. Ancient domestications gave way to a selection of chestnut varieties as well as spontaneous tree populations differentiated genetically in different parts of the Mediterranean basin as a result of genetic flow between selected varieties and wild populations (Mattioni et al. 2008). Current practices, in a context of fast changes in landscape dynamics, new uses of varieties, and soil changes due to terrace abandonment, are likely to give way to new domestications and promote new diversities as shown by ongoing selection practices by newcomers in Cévennes.

Through looking at changes at different scales we identify a common pattern between the society and the ecology of its agroecosystem following the social-ecological theory 
developed by Folke et al. (2003). Throughout the periods of decline and the period of revival, the society passes through periods of social disorganization and de-domestication or reversion to a wild and spontaneous status of the ecology of its agroecosystem and back to social reorganization, reappropriation of ancient varieties, and new domestication processes. This reversibility from cultivation to wilder statuses forms part of the specificities of rural or domestic forests (Michon et al. 2007, Genin et al. 2010) intrinsically linked to the human setups. They represent truly biocultural objects lying beyond the divide between nature and culture (Descola 2006).

One may wonder about the limits of the changes operating. Although chestnut varieties are named and transferred through vegetative propagation with built reputations over many generations thus enabling their perpetuation, such knowledge is being lost with changing use patterns. The capacity of younger generations and newcomers to identify some of these varieties is very low and the passing away of oldest inhabitants will represent a drastic loss in memory. Specialization of productions based on one or two varieties may lead to more vulnerability especially in contexts of expected climate change in the region, a situation also expected on other crops in other areas (IPCC 2007, Bellon et al. 2011). New landscape mosaics produced in both RFs show an important shift from the more integrative traditional agro-silvo-pastoral model toward a new pattern still under construction with specialized spaces and productions, e.g., fruit-timber-animal breeding. A strong gap indeed still persists between practices proposed by the forestry and the agricultural sectors that tend to support forestry or agricultural projects separately. The major decrease in pastoral activity also raises issues of soil fertility and overall capacity to contain scrub vegetation encroachment, a common feature prevailing throughout the Mediterranean region regarding agro-silvo-pastoral systems (Aranzabal et al. 2004).

Practices have been expanded in the course of the renewal processes to include new actors with different sets of knowledge showing the importance of cross-scale exchanges in contexts of crisis (Anderies et al. 2006). This represents a driving force for institutional changes and capacity of producers to mobilize policies within complex time and space scales between local, regional, national, and global levels. These linkages were developed in the context of institutional changes and collective actions providing effective social change. Such cross-scale and cross-level interactions have proved in other areas to be very effective in influencing policy making, approaches termed as network governance (Torfing 2005, Hirschi 2010). The fragility and strength of these new systems need to be better understood especially regarding the possible negative back loop effects of new governance systems (Anderies et al. 2006). We show how different policies have been mobilized by such networks but this situation may be vulnerable because of lack of effective exchanges between the local levels and decision making levels. Environmental policies, for example, have favored rehabilitation and are likely to expand through the new orientations of the European Common Agricultural Program. The European Directive CEE92/43 labeled Mediterranean savannas, including seminatural chestnut tree planted orchards as well as holmoak dominated garrigues, as eligible ecosystems to be funded for restoration programs. However, values carried by such policies may not effectively correspond to the values and social-ecological dynamics of these SESs; the SES's socioeconomic objectives are not built into such policies, which aim mainly for biodiversity and environmental services management.

\section{CONCLUSION}

Although these two SESs have undergone a long period of crisis, social-ecological legacies comprising domestication at different integrated scales, and innovations linked to changes in society have contributed to their resilience. The dynamic exchange between social-ecological legacies and innovations is an important avenue for reflecting on new durable agricultural systems adapted to modern contexts. The truffle holm-oak or the chestnut RFs are good models for reflections on the importance of domestication processes as part of socialecological legacies. Taking integrated ecological scales in SESs into consideration may help in designing resilient agroecosystem management systems. These two rural forests are very similar to many highly productive systems developed by rural societies, such as the Dehesa in Spain, the Montados in Portugal, and many similar systems found throughout the Mediterranean basin. These highly productive agro-silvopastoral areas including cereals, tree, and animal productions combining high biodiversity and good ecosystem services show a high adaptive capacity in times of crisis. Environmental policies that value biodiversity and ecosystem services need to consider the complexity of these SESs that cannot obviously be reduced to simple payments for ecosystem services. Multisector policies require integrated approaches including both forestry and agricultural approaches taking into account social-ecological dynamics including transmission of legacies and innovations. They require restoration projects and agroecological engineering approaches that build on sound understanding of ecological dynamics, as well as cross-scale exchanges of knowledge between local knowledge holders, regional, national, and international levels.

${ }^{[1]}$ Figures of conversion of francs into equivalent values in euro taking into consideration cost of life and other indexes are not available in the INSEE Archives before 1900. We use the figure for the closest period of 1868 .

Responses to this article can be read online at: http://www.ecologyandsociety.org/voll7/iss2/art12/ responses/ 


\section{Acknowledgments:}

We are thankful to the 'Agence National de la Recherche' (ANR) for funds provided through the POPULAR project. We thank all colleagues and inhabitants in Cévenne and Uzès, the Syndicat des Trufficulteurs du Gard, and especially President Mr. Michel Tournayre. We are also grateful to the Chambre d'Agriculture du Gard, Mrs Béatrice Ladrange, and Mr. Bernard Assenat for their help and for providing information. We also thank Hubert de Foresta who followed the work of Clara Therville in Uzès. The ANR project SYSTRUF is acknowledged for providing support to follow up on work undertaken on the truffle holm-oak agroecosystem in Uzès. We are very grateful to Dr. Alan Hamilton who reviewed the first manuscript and to Professor Doyle McKey who has made numerous comments and corrections on this text and has greatly helped in improving this paper.

\section{LITERATURE CITED}

Anderies, J. M., B. H. Walker, and A. P. Kinzig. 2006. Fifteen weddings and a funeral: case studies and resilience-based management. Ecology and Society 11(1): 21. [online] URL: http://www.ecologyandsociety.org/vol11/iss1/art21/

Aranzabal, I., M. Schmitz, P. Aguilera, and F. Pineda. 2008. Modelling of landscape changes derived from the dynamics of socio-ecological systems: a case of study in a semiarid Mediterranean landscape. Ecological Indicators 8:672-685. http://dx.doi.org/10.1016/j.ecolind.2007.11.003

Auclair, L., P. Baudot, D. Genin, B. Romagny, and R. Simenel. 2011. Patrimony for resilience: evidence from forest Agdal in the Moroccan High Atlas Mountains. Ecology and Society 16 (4): 24. http://dx.doi.org/10.5751/ES-04429-160424

Aumeeruddy-Thomas, Y. 2010. Des clones aux semis: domestication des arbres en méditerranée, un continuum entre nature et culture. Exemples de Ficus carica L., Olea europaea L. et Castanea sativa Mill. In C. Delhon, I. Théry-Parisot, and S. Thiébault, editors. Des Hommes et des plantes. Exploitation du milieu et des ressources végétales de la préhistoire à nos jours. Editions APDCA, Antibes, France.

Barthel, S., C. Folke, and J. Colding. 2010. Social-ecological memory in urban gardens - retaining the capacity for management of ecosystem services. Global Environmental Change 20:255-265. http://dx.doi.org/10.1016/j.gloenvcha.20 $\underline{10.01 .001}$

Bellon, M. R., D. Hodson, and J. Hellin. 2011. Assessing the vulnerability of traditional maize seed systems in Mexico to climate change. PNAS 108(33):13432-13437. http://dx.doi.or g/10.1073/pnas.1103373108

Berkes, F., J. Colding, and C. Folke, editors. 2003. Navigating social-ecological systems: building resilience for complexity and change. Cambridge University Press, Cambridge, UK.
Bruneton-Governatori, A. 1984. Le pain de bois. Une ethnohistoire de la châtaigne et du châtaignier. Eché, Toulouse, France.

Callot, G. 1999. La truffe, la terre, la vie. INRA, Paris, France.

Chatin, A. D. 1892. La truffe. Baillères, Paris, France.

Chazoule, C. 2004. L'histoire inachevée de la domestication des truffière. Ruralia 15. [online] URL: http://ruralia.revues.o rg/document1029.html

Dalonis, S. 1996. Etat de la trufficulture française en 1996 illustré au travers de l'espace de production gardois. Thesis. Université Paul Valéry, Montpellier, France.

de Bosredon, A. 1887. Manuel du trufficulteur. Ed C. Lacour, Nîmes, France.

Descola P. 2006. Par-delà nature et culture. Gallimard, Bibliothèque des Sciences Humaines, Paris, France.

Diette, S., and A. Lauriac. 2004. La sylviculture truffière: aperçus historiques, apports techniques et enjeux pour la région méditeranéenne. La Revue Forestière Française 3:219-230. http://dx.doi.org/10.4267/2042/5094

Dove, M. R. 1999. The agronomy of memory and the memory of agronomy: ritual conservation of archaic cultigens in contemporary farming systems. Pages 45-70 in V. Nazarea, editor. Ethnoecology: situated knowledge/located lives. The University of Arizona Press, Tucson, Arizona, USA.

Dove, M. R. 2002. Histoires et savoirs autochtones hybrides chez les petits cultivateurs d'hévéa d'Asie. Revue Internationale des Sciences Sociales 173:389-400. http://dx.d oi.org/10.3917/riss.173.0389

Dupré, L. 2002. Du marron à la châtaigne d'Ardèche, la relance d'un produit régional. Ed. Comité des Travaux Historiques et Scientifiques, Paris, France.

Fédération Française des Trufficulteurs (FFT). 2005. L'impact socio-économique de la trufficulture sur le développement local. Etude réalisée avec le concours du Fond National d'Aménagement et de Développement du Territoire, FFT, Paris, France.

Folke, C., J. Colding, and F. Berkes. 2003. Synthesis: building resilience and adaptive capacity in social-ecological systems. Pages 352-387 in F. Berkes, J. Colding, and C. Folke, editors. Navigating social-ecological systems: building resilience for complexity and change. Cambridge University Press, Cambridge, UK. http://dx.doi.org/10.1017/CBO97805115419 $\underline{57.020}$

Galzin, J., and R. Dejean. 1986. Déboisement et plantation de châtaigniers en Cévennes. Annales du Parc national des Cévennes 103:7-70.

Genin, D., Y. Aumeeruddy-Thomas, G. Balent, and G. Michon. 2010. A framework for characterizing convergence 
and discrepancy in rural forest management in tropical and temperate environments. Pages 718-723 in J. C. Azevado, M. Feliciano, J. Castro, and M. A. Pinto, editors. Forest Landscapes and Global Change. New Frontiers in Management, Conservation and Restoration. IUFRO Proceedings, Instituto Politéchnico de Bragança, Bragança, Portugal.

Gepts, P., R. F. Famula, R. L. Bettinger, S. B. Brush, A. B. Damania, P.E. McGuire, and C. O. Qualset. 2012. Biodiversity in agriculture. Domestication, evolution, and sustainability. Cambridge University Press, Cambridge, UK.

Gondard, H., F. Romane, M. Grandjanny, J. Li, and J. Aronson. 2001. Plant species diversity changes in abandoned chesnut (Castanea sativa) groves in southern France. Biodiversity and Conservation 10:189-207. http://dx.doi.org/10.1023/A:10089 $\underline{97625523}$

Grove, A. T., and O. Rackham. 2001. The nature of Mediterranean Europe. Yale University Press, New Haven, Connecticut, USA.

Gunderson, L. H., and C. S. Holling, editors. 2002. Panarchy: understanding transformations in human and natural systems. Island Press, Washington, D.C., USA.

Hall, I. R., T. Gordon, T. Brown, and A. Zambonelli. 2007. Taming the truffle. The history, lore and science of the ultimate mushroom. Timber Press, Portland, Oregon, USA.

Hall, I. R, W. Yun, and A. Amicucci. 2003. Cultivation of edible ectomycorrhizal fungi. Trends in Biotechnology 21 (10):433-438. http://dx.doi.org/10.1016/S0167-7799(03)00204$\underline{X}$

Hirschi, C. 2010. Strengthening regional cohesion: collaborative networks and sustainable development in Swiss rural areas. Ecology and Society 15(4): 16. [online] URL: htt p://www.ecologyandsociety.org/vol15/iss4/art16/

Intergovernmental Panel on Climate Change (IPCC). 2007. Climate change 2007: the physical science basis. Contribution of Working Group I to the Fourth Assessment Report of the Intergovernmental Panel on Climate Change. S. Solomon, D. Qin, M. Manning, Z. Chen, M. Marquis, K. B. Averyt, M. Tignor, and H. L. Miller, editors. Cambridge University Press, Cambridge, UK.

Lemarchand, C. 2009. Étude d'un système socio-écologique: la châtaigneraie cévenole, commune de Saint Martin de Lansuscle, Lozère. ANR POPULAR, CEFE, Thesis, University Montpellier II, Montpellier, France.

Mattioni, C., M. Cherubini, E. Micheli, F. Villani, and G. Bucci. 2008. Role of domestication in shaping Castanea sativa genetic variation in Europe. Tree Genetics \& Genomes 4:563-574. http://dx.doi.org/10.1007/s11295-008-0132-6
Michon, G., H. De Foresta, P. Levang, and F. Verdeaux. 2007. Domestic forests: a new paradigm for integrating local communities' forestry into tropical forest science. Ecology and Society 12(2): 1. [online] URL: http://www.ecologyands ociety.org/vol12/iss2/art1/

Nazarea, V. D. 1998. Cultural memory and biodiversity. University of Arizona Press, Tucson, Arizona, USA.

Ollagnon, H. 2000. La gestion en patrimoine commun de la qualité de l'eau dans un basin. Pages 325-345 in M. Falque and M. Massenet, editors. Les ressources en eau. Droits de propriété, économie et environnement. Dalloz, Paris, France.

Pelen, L. N. 1987. L'autrefois des Cévenols. Edisud, Aix en Provence, France.

Pitte, J. R. 1986. Terres de Castanide. Hommes et paysages du châtaignier de l'Antiquité à nos jours. Ed. Fayard, Paris, France.

Quézel, P., and F. Médail. 2003. Ecologie et biogéographie des forêts du bassin méditerranéen. Elsevier, Paris, France.

Scarascia-Mugnozza, G., H. Oswald, P. Piussi, and K. Radoglou. 2000. Forests of the Mediterranean region: gaps in knowledge and research needs. Forest Ecology and Management 132:97-109 http://dx.doi.org/10.1016/S0378-1127 (00)00383-2

Sutherland, W. J. 2002. Restoring a sustainable countryside. Trends in Ecology \& Evolution 17(3):148-150. http://dx.doi.o rg/10.1016/S0169-5347(01)02421-1

Therville, C. 2009. Caractérisation de la place de la trufficulture dans le paysage naturel et culturel d'Uzès. Thesis, University Montpellier II, Montpellier, France.

Torfing, J. 2005. Governance network theory: towards a second generation. European Political Science 4:305-315. http://dx.doi.org/10.1057/palgrave.eps.2210031

Travier, D. 2006 Que sait-on de l'histoire de la châtaigneraie Cévenole? Pages 23-31 in J.-P. Chassany and C. Crosnier, editors. Le renouveau de la châtaigneraie Cévenole. Editions du Parc National des Cévennes, Florac, France.

Travier, D., J.-N. Pelen. 1973. Le temps cévenol, la mémoire d'une terre. First edition, IV, vol. 1, Sédilan, Nîmes, France.

Verdier, G. 2006. Les variétés traditionnelles de châtaignes en Cévennes. Pages 62-70 in J.-P. Chassany and C. Crosnier, editors. Le renouveau de la châtaigneraie Cévenole. Editions du Parc National de Cévennes, Florac, France.

Walker B., C. S. Holling, S. R. Carpenter, and A. Kinzig. 2004. Resilience, adaptability and transformability in socialecological systems. Ecology and Society 9(2) : 5. [online] URL: http://www.ecologyandsociety.org/vol9/iss2/art5 